\title{
Pembuatan Kolom Monolit Mixed-Mode untuk Pemisahan Fenol dalam Kromatografi Cair Sistem Kapiler
}

\author{
Aster Rahayu ${ }^{1 *}$, Joni Aldilla Fajri², Lee Wah Lim³, Toyohide Takeuchi ${ }^{3}$ \\ ${ }^{1}$ Program Studi Teknik Kimia, Fak. Teknologi Industri Universitas Ahmad Dahlan, Kampus III, Jl. Soepomo, Janturan, Warungboto, Yogyakarta 55164 \\ ${ }^{2}$ Program Studi Teknik Lingkungan, Fak. Teknik Sipil dan Perencanaan Universitas Islam Indonesia, Jalan Kaliurang Km.14,5, Sleman, Yogyakarta 55584 \\ ${ }^{3}$ Department of Chemistry and Biomolecular Science, Faculty of Engineering, Gifu University, Gifu-shi, Yanagido 1-1, Japan 501-1193 \\ ${ }^{1}$ aster.rahayu@che.uad.ac.id*; \\ * corresponding author
}

ARTICLE INFO

Article history

Received January 11, 2019

Revised March 28, 2019

Accepted April 02, 2019

\section{Keywords}

Monolit polimer

Pentaeritrytol Tetraacrylate-Ethylene

dimathacrylate

Mixed-mode Liquid Chromatography

HILIC

Reverse Phase Liquid Chromatography

\section{ABSTRACT}

A Mixed-Mode monolithic column prepared from Pentaeritrytol Tetraacrylate (PETRA) and Ethylene dimathacrylate (EDMA) was investigated and used in capillary liquid chromatography. The polymer composition was optimized by varying percentage ratio of monomer and porogens. Column A with rasio 35/65 (monomer/porogen) showed the optimum ratio. The polymerization of acrylic groups were conducted by in-situ preparation in capillary fused silica. Three phenol compounds were separated using this monolithic column using acetonitrile $100 \%$ as eluent. Monolith PETRA-EDMA also could work to separate polar and non-polar compound simultaneously by HILIC mode using acetonitrile $90 \%$ as eluent. The morphology surface of monolith was observed by scanning electron microscope (SEM) and mechanical stability in term of pressure drop was observed as well.

\section{Pendahuluan}

Pemisahan beberapa campuran senyawa dalam sampel komplek secara analitik menjadi semakin penting beberapa tahun terakhir ini, karena semakin pesatnya perkembangan ilmu dalam bidang proteomik, metabolisme, ilmu lingkungan, dan kimia obat. Metode High Performance Liquid Chromatografi (HPLC) merupakan salah satu metode analitik yang telah banyak digunakan dalam memisahkan senyawa campuran berdasarkan interaksi khususnya Reverse Phase Liquid Chromatography (RPLC). Dalam RPLC, teknik pemisahan dilakukan berdasarkan interaksi hidrofobik yang terjadi di dalam kolom pemisah [1-5]. Akan tetapi, untuk senyawa yang memiliki sifat kepolaran yang sangat tinggi, pemisahan dengan menggunakan metode RPLC tidak cukup efisien karena senyawa akan tertahan lebih lama di dalam kolom pemisah yang memilik sifat hidrofobik yang tinggi. Sehingga pada kondisi tersebut, pemisahan dengan menggunakan metode yang dikenal dengan Hidrophilic Interaction Liquid Chromatography (HILIC) menjadi pilihan [6-8]. Meskipun demikian, pemisahan sampel yang lebih kompleks dengan melibatkan kombinasi senyawa hidrofobik dan hidrofilik, dan hanya menggunakan satu kolom pemisah menjadi tantangan pada analisa dengan HPLC metode tunggal. Maka dari itu, teknik pemisahan yang mengandung interaksi hidrofilik dan hidrofobik pada mekanisme retensi campuran senyawa menjadi pilihan.

Mixed-Mode Liquid Chromatography (MMLC) merupakan suatu teknik pemisahan kromatografi cair untuk memisahkan kombinasi senyawa yang bersifat hidrofilik dan hidrofobik yang sulit dilakukan hanya dengan menggunakan satu kolom pemisah pada HPLC metode tunggal. MMLC telah banyak berkembang untuk mengatasi permasalah dalam pemisahan sampel protein, alkilbenzen, amina dan nukleosida [9-12].

Belakangan ini telah banyak organik polimer monolit yang telah dikembangkan untuk digunakan dalam pemisahan campuran senyawa hidrofilik dan hidrofobik. Organik polimer monolit dibuat melalui proses polimerisasi langsung di dalam kapiler fused silica tube dengan mencampurkan monomer, cross-linker, inisiator dan porogen atau dengan melakukan modifikasi dari polimer dasar yang telah terlebih dahulu dipersiapkan [13]. 
Pada penelitian ini, polimer monolit berdasarkan gugus dasar akrilat akan disintesis hanya dengan satu langkah polimerisasi dan dilakukan langsung di dalam kapiler fused silica tube. Pada penelitian ini, Ethylene dimethacrylate (EDMA) digunakan sebagai cross-linker. EDMA merupakan cross-linker yang sangat reaktif dan memiliki sifat kefleksibelan yang sangat baik, tidak bersifat beracun dan sangat stabil jika digunakan bersamaan dengan bahan kimia lainnya. Sebagai monomer penyedia dasar akrilatnya akan digunakan Pentaeritrytol Tetraacrylate (PETRA). PETRA merupakan suatu bahan kimia yang memiliki struktur yang besar dengan 4 terminal karbon dengan gugus dasar akrilat bagian ujungnya. Diharapkan polimer PETRA-EDMA memiliki struktur polimer monolit yang besar dengan pori makro yang baik sehingga dapat menghasilkan kolom monolit yang akan digunakan dalam pemisahan senyawa fenol dengan tekanan sistem yang kecil.

\section{Metodologi}

\subsection{Bahan}

Bahan yang digunakan meliputi Pentaeritrytol Tetraacrylate (PETRA) sebagai monomer, Ethylene dimethacrylate (EDMA) sebagai cross-linker, PEG 200 (Nacalai Tesque, Kyoto, Japan). 3(trimethoxysilyl)-propyl methacrylate ( $\gamma$-MAPS) (Trade TCI Mark), Metanol, Aseton, Azobisisobutyronitrile (AIBN), Air deionisasi (air yang telah diketahui konduktifitasnya dan khusus digunakan untuk kromatografi ion) GS-590 water destilation system (Advantec, Tokyo, jepang), larutan standar fenol, pirogalol, pirokatekol, toluen dan urasil (Nacalai Tesque, Kyoto, Japan).

\subsection{Alat}

Rangkaian peralatan Kromatografi Cair Sistem Kapiler terdiri dari microfeeder (L.TEX Corporation, Tokyo Japan) yang menggunakan gas-tight syringe ( $0.5 \mathrm{ml}$; Ito, Fuji, Japan) sebagai pompa, 6-way switching valve dengan volume injeksi $0.2 \mu \mathrm{l}$ yang berfungsi sebagai injektor (Upchurch Scientific, Oak Harbor, WA, USA), Kolom monolit sebagai kolom pemisah disiapkan pada kapiler fused silica tube (0.32 mm I.D x $0.45 \mathrm{~mm}$ O.D; GL Science, Tokyo, Japan) dengan panjang $100 \mathrm{~mm}$. UV-2075 intelligent UV/VIS sebagai detektor, (JASCO) Tokyo, Japan) yang dioperasikan pada panjang gelombang $210 \mathrm{~nm}$. Chromatopac C-R7A sebagai data prosesor (Shimadzu, Kyoto, Japan). Morfologi permukaan dari kolom monolit dikarakterisasi dengan menggunakan Scanning Electron Microscope (SEM) S-4800 (Hitachi, Tokyo, Japan).

\subsection{Persiapan kolom Monolit PETRA-EDMA}

Sebelum digunakan, kapiler fused silica tube dengan ukuran $0.32 \mathrm{~mm}$ i.d. x $0.45 \mathrm{~mm}$ o.d. dibilas secara berurutan dengan $1 \mathrm{M} \mathrm{NaOH}$, air deionisasi dan $1 \mathrm{M} \mathrm{HCl.} 30 \%(\mathrm{v} / \mathrm{v}) \gamma$-MAPS yang dilarutkan dalam aseton digunakan untuk mempersiapkan lapisan dalam kapiler sebelum polimer PETRAEDMA melekat pada permukaan dinding dalam kapiler, kemudian campuran 30\% $\gamma$-MAPS dimasukkan ke dalam kapiler fused silica tube dan kedua ujung kapiler ditutup dan dimasukkan ke dalam waterbath pada suhu $60^{\circ} \mathrm{C}$ selama 24 jam. Kemudian kapiler dibilas dengan aseton dan dikeringkan dengan menggunakan gas nitrogen selama 30 menit. Pembentukan monolit PETRAEDMA yang langsung di dalam kapiler yang dilakukan dengan mencampurkan monomer, crosslinker dan porogen secara bersamaan. 0.1 mL PETRA + $0.15 \mathrm{~mL}$ EDMA + $0.25 \mathrm{~mL}$ PEG $200+$ $0.53 \mathrm{~mL}$ metanol $+2 \mathrm{mg}$ AIBN dimasukkan kedalam botol kaca dan kemudian campuran digetarkan dengan ultrasonic selama 5 menit sebelum dimasukkan ke dalam kapiler fused silica tube yang telah dilakukan perlakukan awal. Reaksi polimerisasi di dalam kapiler dioptimalkan dalam waterbath suhu $60^{\circ} \mathrm{C}$ selama 24 jam. Kemudian kapiler yang berisi polimer PETRA-EDMA dibilas dengan metanol kecepatan alir $2.5 \mu \mathrm{L} /$ min selama 60 menit untuk menghilangkan residu.

\section{Hasil dan Pembahasan}

\subsection{Persiapan Kolom Monolit PETRA-EDMA untuk pemisahan senyawa polar}

Pada penelitian ini kolom monolit PETRA-EDMA dibuat dengan melakukan reaksi polimerisasi langsung di dalam kapiler fused silica tube dengan mencampurkan secara bersamaan monomer, cross-linker, porogen dan inisiator polimer. Kemampuan kolom monolit salah satunya dipengaruhi oleh rasio antara monomer dan porogen yang digunakan. Secara teoritis, semakin sedikit jumlah porogen yang digunakan akan menghasilkan monolit yang sangat padat dan pori makro pada monolit yang terbentuk akan sedikit. Dalam hal ini PEG dan metanol memiliki peran dalam 
pembentukan pori makro pada monolit. Jumlah pori makro nantinya akan berpengaruh terhadap tekanan sistem kromatografi ketika kolom monolit tersebut digunakan sebagai kolom pemisah. Berbagai variasi telah dipersiapkan untuk melihat kemampuan dari kolom monolit PETRA-EDMA seperti pada Tabel 1 .

Table 1. Variasi komposisi polimer PETRA-EDMA

\begin{tabular}{|c|c|c|c|c|c|c|}
\hline \multirow[b]{2}{*}{ Kolom } & \multirow{2}{*}{$\begin{array}{l}\text { Monomer } \\
\text { mL }\end{array}$} & \multirow{2}{*}{$\begin{array}{c}\text { Cross-linker } \\
\mathrm{mL}\end{array}$} & \multicolumn{2}{|c|}{ Porogen } & \multirow{2}{*}{$\begin{array}{c}\text { Rasio } \\
\text { campuran }^{\mathrm{c}}\end{array}$} & \multirow{2}{*}{$\begin{array}{c}\text { Kondisi } \\
\text { polimerisasi }^{\mathrm{d}}\end{array}$} \\
\hline & & & $\begin{array}{c}\text { PEG 200 } \\
\mathrm{mL}\end{array}$ & $\begin{array}{c}\text { Metanol } \\
\text { mL }\end{array}$ & & \\
\hline $\mathrm{A}$ & 0,1 & 0,25 & 0,1 & 0,55 & $35 / 65$ & $60^{\circ} \mathrm{C}, 24 \mathrm{jam}$ \\
\hline B & 0,09 & 0,21 & 0,11 & 0,59 & $30 / 70$ & $60{ }^{\circ} \mathrm{C}, 24 \mathrm{jam}$ \\
\hline $\mathrm{C}$ & 0,07 & 0,18 & 0,12 & 0,63 & $25 / 75$ & $60{ }^{\circ} \mathrm{C}, 24 \mathrm{jam}$ \\
\hline $\mathrm{D}$ & 0,06 & 0,14 & 0,12 & 0,68 & $20 / 80$ & $60{ }^{\circ} \mathrm{C}, 24 \mathrm{jam}$ \\
\hline
\end{tabular}

${ }^{a}$ Pentaeritrytol Tetraacrylate (PETRA) sebagai monomer

${ }^{\mathrm{b}}$ Ethylene dimethacrylate (EDMA) sebagai cross-linker

${ }^{\mathrm{c}}$ Total volume rasio dari monomer + cross-linker terhadap porogen

${ }^{\mathrm{d}}$ Reaksi polimerisasi Dilakukan pada suhu $60{ }^{\circ} \mathrm{C}$ selama 24 jam

Empat variasi rasio yaitu 35/65, 30/70, 25/75 dan 20/80 disiapkan untuk melihat pengaruhnya terhadap tekanan sistem. Pada Gambar 1. terlihat adanya hubungan antara rasio campuran dengan tekanan sistem yang dihasilkan ketika kolom monolit PETRA-EDMA digunakan sebagai kolom pemisah pada sistem kromatograsi cair. Pada kolom monolit dibentuk dari 65\% porogen menghasilkan tekanan sistem yang cukup tinggi yaitu $1 \mathrm{MPa}$ (kecepatan alir fasa gerak $2 \mu \mathrm{L} / \mathrm{menit}$ ). Sedangkan pada rasio yang digunakan $80 \%$, nilai tekanan sistem adalah 0,6 MPa. Nilai ini mendekati nilai tekanan sistem pada penelitian sebelumnya, monolit metakrilat-PEG dengan $80 \%$ porogen dan monolit PEG-PEGDMA dengan $78 \%$ porogen menghasilkan tekanan sistem yang sama $0,5 \mathrm{MPa}$ pada kecepatan alir fasa gerak $2 \mu \mathrm{L} /$ menit [14,15]. Dengan meningkatnya persentase porogen dalam campuran akan menghasilkan tekanan lebih rendah. Hal ini disebabkan semakin banyaknya pori makro yang terbentuk dan sebaliknya dengan sedikitnya persentase porogen akan menghasilkan monolit yang padat dan keras, hal ini disebabkan oleh sedikitnya pori makro yang terbentuk. Kolom A dengan rasio 35/65 adalah kondisi optimum pembentukan kolom monolit PETRA-EDMA dan untuk investigasi profil kolom selanjutnya akan menggunakan kolom A.

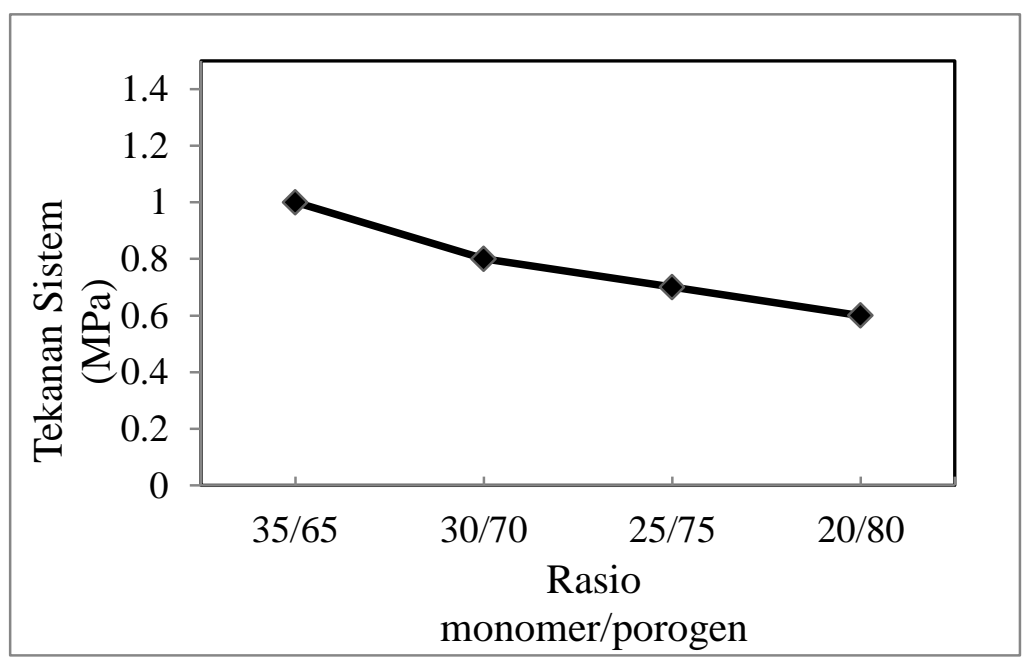

Gambar 1. Pengaruh rasio monomer/porogen terhadap nilai tekanan sistem kromatografi cair sistem kapiler dengan kecepatan alir fasa gerak $2 \mu \mathrm{l} /$ menit. 
Untuk melihat kemampuan kolom monolit PETRA-EDMA dalam memisahkan senyawa polar dengan interaksi Reverse Phase $(R P)$, campuran tiga senyawa polar yaitu fenol, pirogalol dan pirokatekol dipisahkan dengan mengunakan kolom monolit PETRA-EDMA pada kondisi sistem kromatografi yang sama. Gambar 2. menampilkan profil pemisahan senyawa polar dengan menggunakan kolom A, B, C dan D. Pemisahan ketiga senyawa polar tersebut berhasil dilakukan dengan menggunakan kolom $\mathrm{A}$, sedangkan dengan menggunakan kolom $\mathrm{B}, \mathrm{C}$ dan $\mathrm{D}$, untuk ketiga senyawa tersebut terdeteksi pada waktu retensi yang sama. Ini diartikan, kolom B, C dan D tidak memiliki kemampuan yang cukup dalam memisahkan senyawa polar (fenol, pirogalol dan pirokatekol). Pada kolom A persentase monomer yang digunakan pada saat polimerisasi lebih besar dibanding persentase monomer pada kolom yang lainnya, gugus karboksil dan akrilat yang disumbangkan dari monomer memiliki peran yang cukup signifikan terhadap profil pemisahan senyawa polar dengan interaksi RP.

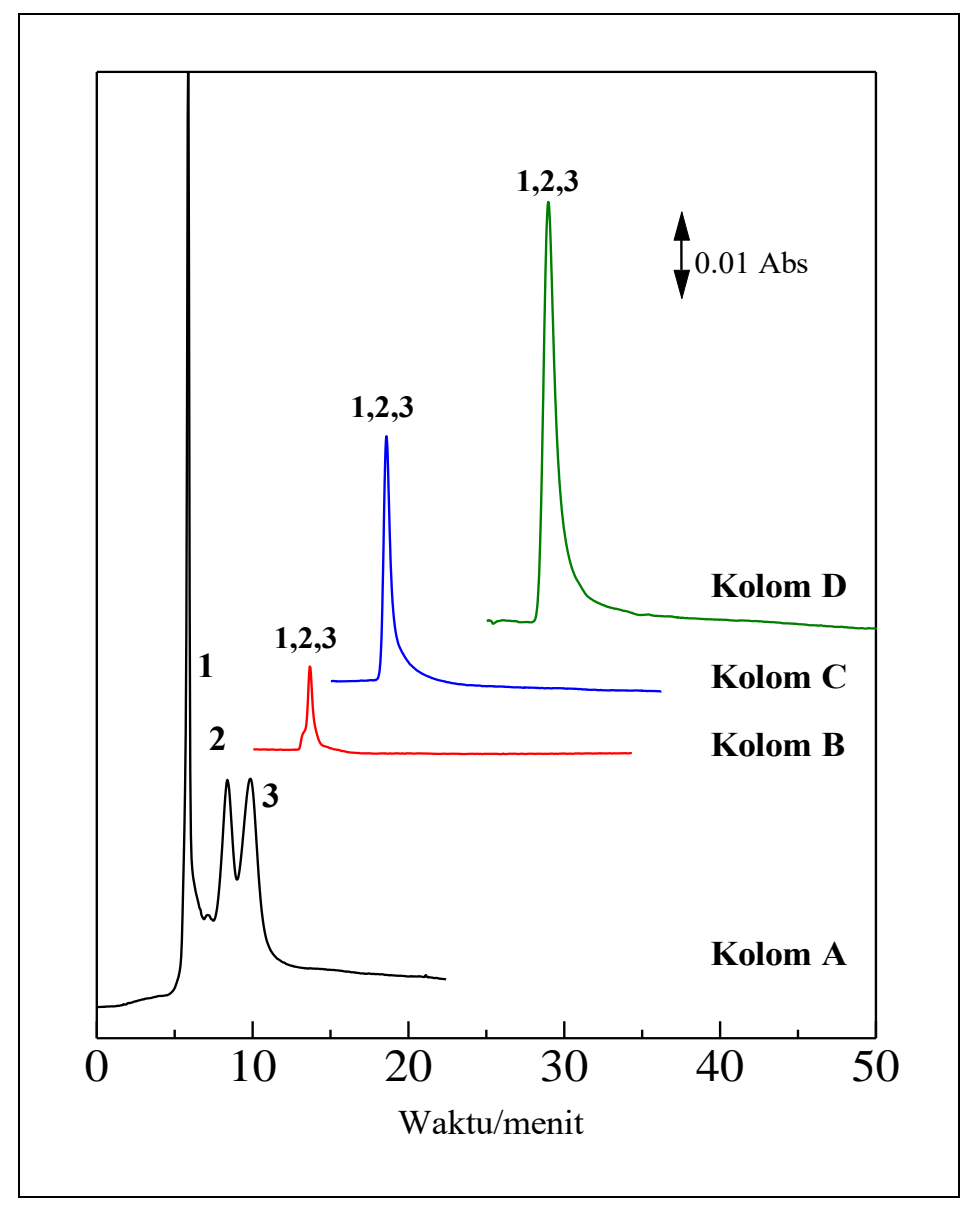

Gambar 2. Profil pemisahan fenol. Kondisi operasi sistem kromatografi cair : Kolom A (PETRA-EDMA rasio 35/65), (100 x 0,32 mm i.d); Analit 0,1\% (w/v) masing-masing (1) fenol, (2) pirogalol, (3) pirokatekol; fasa gerak, Acetonitril 100\%; Volume injeksi, 0,02 $\mu \mathrm{L}$; Detektor, UV detector $256 \mathrm{~nm}$; Kecepatan alir fasa gerak, $2 \mu \mathrm{L} /$ menit.

\subsection{Optimasi Konsentrasi Fasa Gerak}

Pada Gambar 2. Kolom A yang mengandung 35\% monomer+cross-linker dapat digunakan dalam pemisahan senyawa polar dengan interasi RP. Untuk mengoptimalkan pemisahan, dilakukan pengujian terhadap variasi konsentrasi dari fasa gerak yang digunakan. Hal ini bertujuan untuk mendapatkan kondisi optimum terhadap pemisahan senyawa fenol yang bersifat polar. Gambar 3. Menampilkan pengaruh konsentrasi fasa gerak terhadap profil pemisahan senyawa fenol, pirogalol dan pirokatekol. Semakin tinggi konsentrasi asetonitril yang digunakan, maka profil pemisahan semakin baik. Untuk konsentrasi asetonitril 100\%, fenol, pirogalol dan pirokatekol dapat terpisah 
dengan sempurna. Sedangkan pada konsentrasi $50 \%$, fenol, pirogalol dan pirokatekol tidak dapat terpisahkan dengan baik.

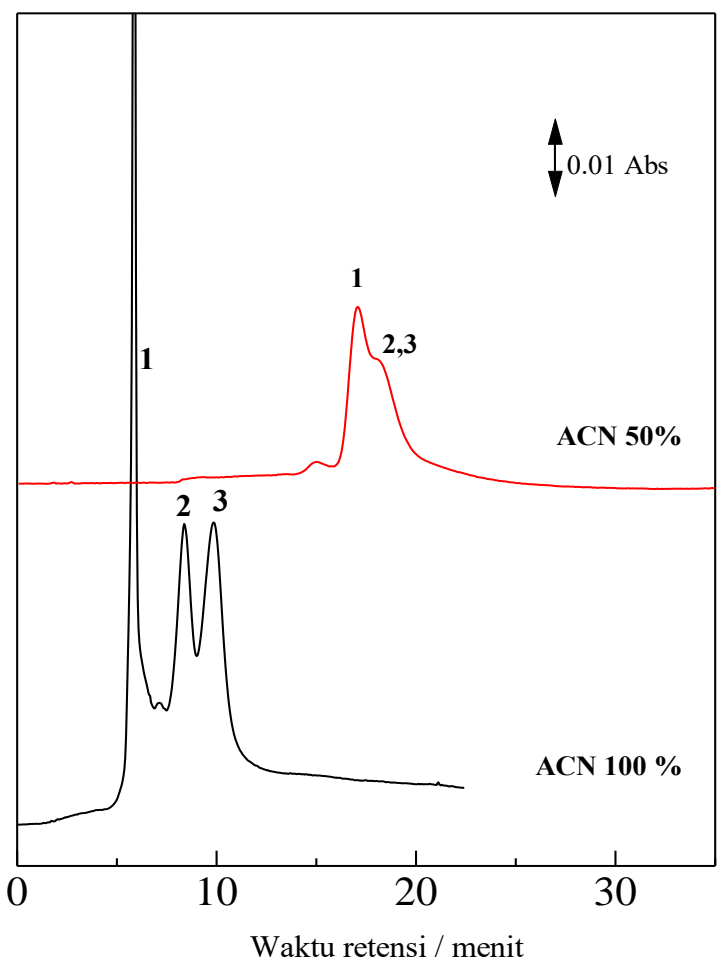

Gambar 3. Pengaruh konsentrasi fasa gerak terhadap profil permisahan fenol. Kondisi operasi sistem kromatografi cair : Kolom A (PETRA-EDMA rasio 35/65), (100 x 0,32 mm i.d); Analit 0,1\% (w/v) masing-masing (1) fenol, (2) pirogalol, (3) pirokatekol; fasa gerak, Acetonitril 50 dan 100\%; Volume injeksi, 0,02 $\mu \mathrm{L}$; Detektor, UV detector $256 \mathrm{~nm}$; Kecepatan alir fasa gerak, $2 \mu \mathrm{L} / \mathrm{menit}$.

\subsection{Karakterisasi Permukaan Monolit PETRA-EDMA}

Morfologi permukaan dari kolom monolit PETRA-EDMA dapat dilihat pada Gambar 4-7. Dari hasil Scanning Electron Microscope (SEM), dapat terlihat kolom A yang terbentuk dari 35\% monomer dan hanya $65 \%$ porogen, dihasikan monolit yang sangat padat. Pori makro yang terbentuk hanya sedikit. Sehingga morfologi permukaan kolom A terlihat lebih padat dan rigit dibandingkan kolom B, C dan D. Dengan berkurangya persentase monomer dan meningkatnya persentasi porogen, bentuk morfologi permukaan kolom monolit pun lebih renggang dan dapat terliat adanya pori makro.
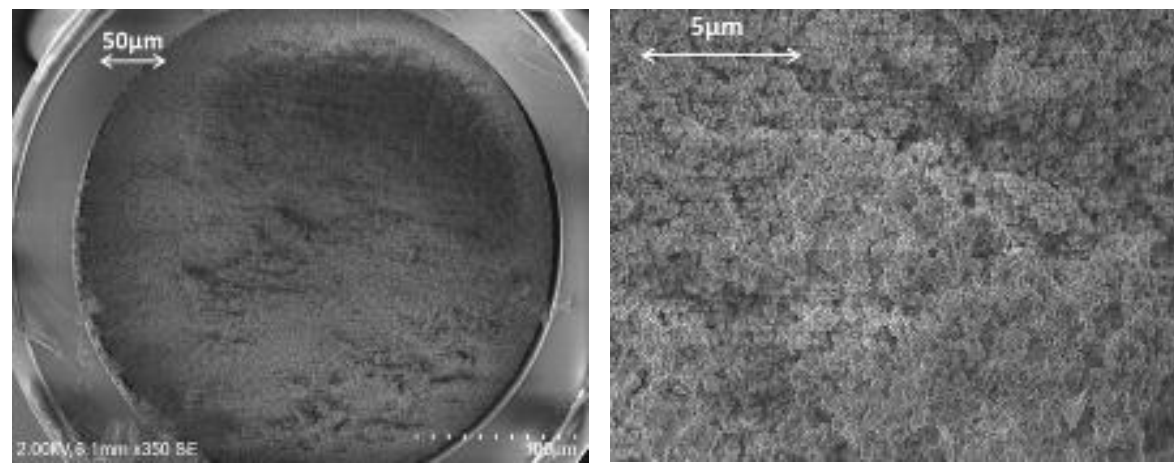

Gambar 4. Foto Scanning Electron Microscope (SEM) monolit PETRA-EDMA (kolom A) 

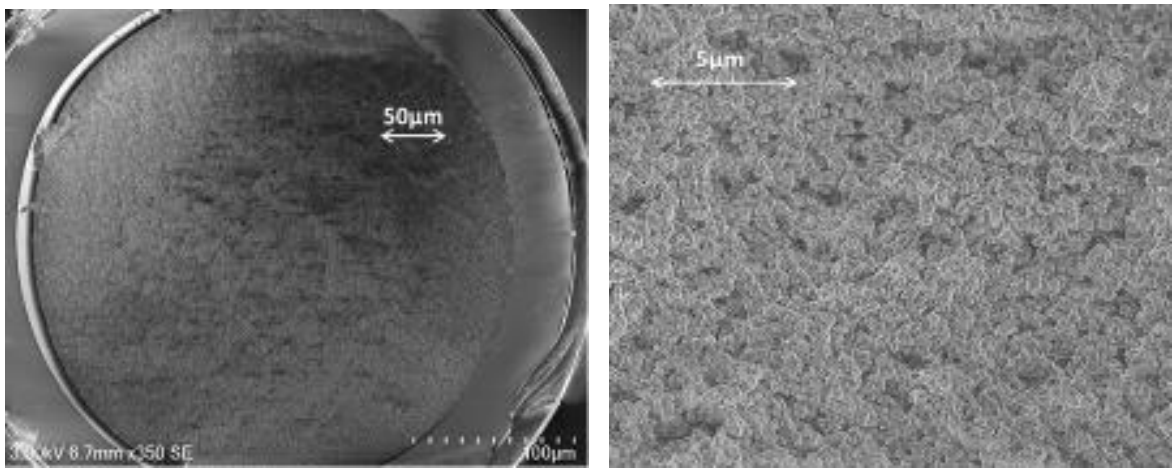

Gambar 5. Foto Scanning Electron Microscope (SEM) monolit PETRA-EDMA (kolom B)
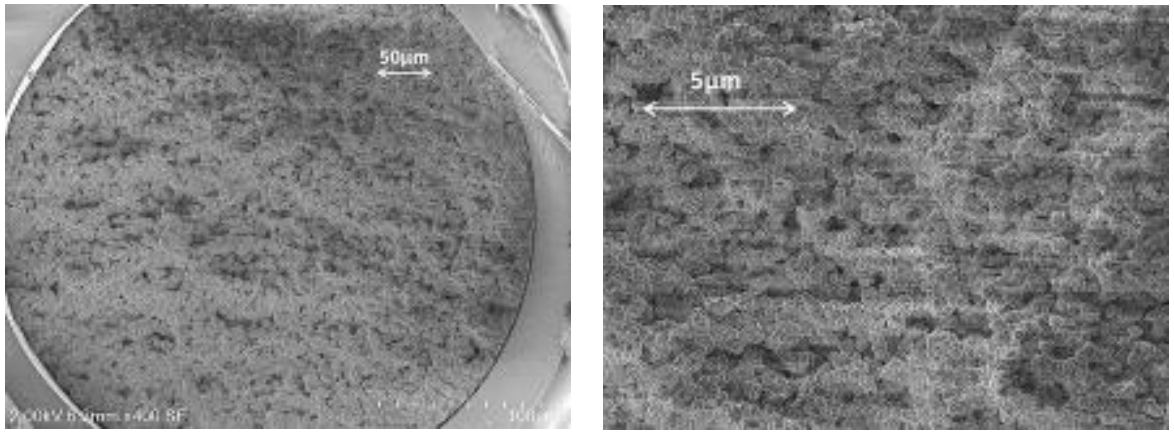

Gambar 6. Foto Scanning Electron Microscope (SEM) monolit PETRA-EDMA (kolom C)
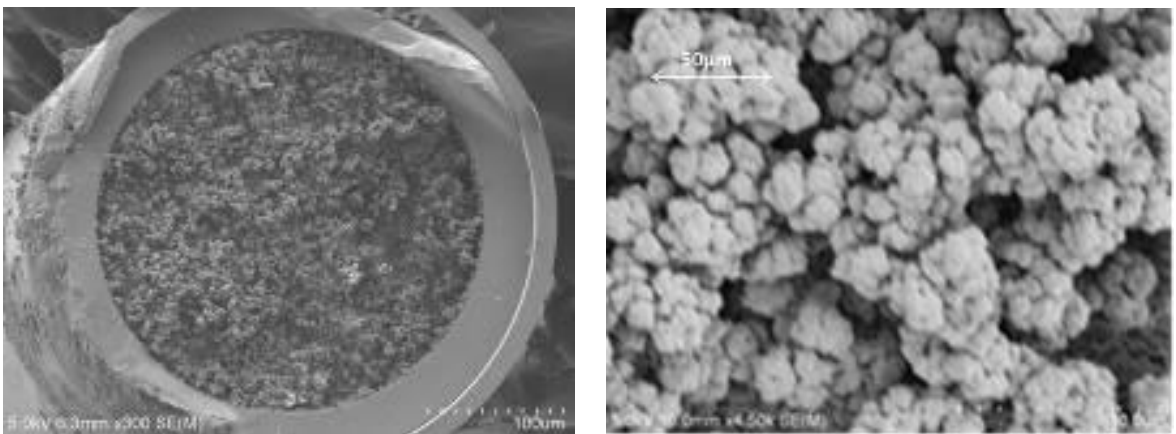

Gambar 7. Foto Scanning Electron Microscope (SEM) monolit PETRA-EDMA (kolom D)

\subsection{Evaluasi HILIC}

Untuk menguji sifat HILIC pada kolom A dengan rasio 35/65 (monomer/porogen), dilakukan uji terhadap pemisahan urasil dan toluen dengan menggunakan berbagai variasi konsentrasi asetonitril yang bertindak sebagai fasa gerak. Urasil dan toluen banyak digunakan sebagai senyawa pengujian sifat HILIC dalam suatu kolom pemisah pada kromatografi cair, hal ini disebabkan urasil dan toluene memiliki sifat kepolaran yang berbeda. Pengujian dilakukan menggunakan asetonitril dengan konsentrasi 60-100\% sebagai fasa gerak. Pada Gambar 8. Menunjukkan waktu retensi urasil dan toluen sebagai analit terhadap asetonitril sebagai fasa gerak. Waktu retensi dari urasil meningkat perlahan dengan meningkatnya konsentrasi asetonitril sedangkan waktu retensi toluen mengalami penurunan dengan meningkatnya konsentrasi asetonitril. Pada konsentrasi terendah asetonitril, urasil terelusi terlebih dahulu dan kemudian terelusi setelah toluene pada konsentrasi tertinggi asetonitril. Hal ini menunjukkan kolom monolit PETRA-EDMA dapat bekerja pada senyawa yang bersifar polar dan non polar. Transisi interaksi HILIC ke RP terjadi pada konsentrasi asetonitril $90 \%$. 


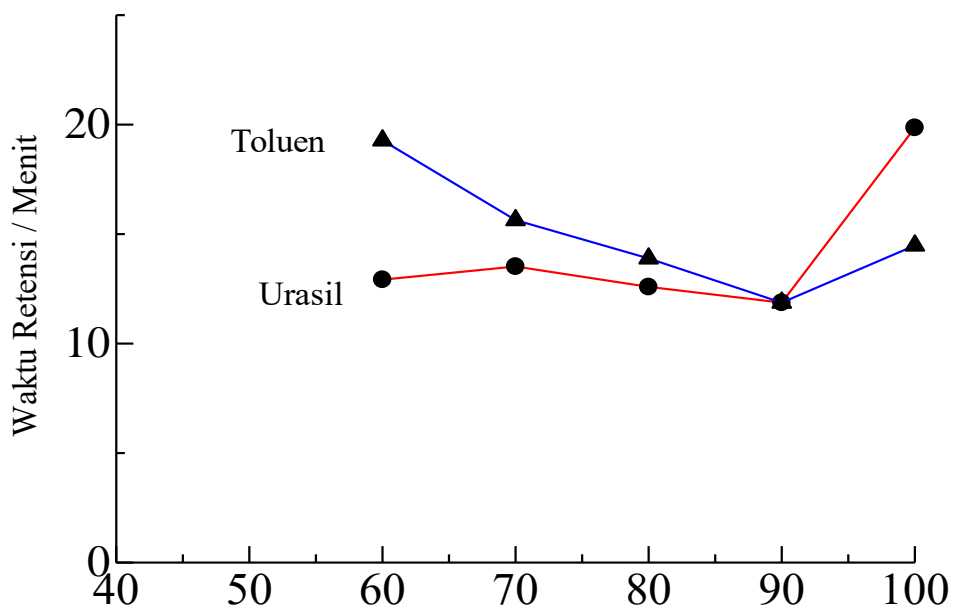

Konsentrasi Asetonitril / \%

Gambar 8. Waktu retensi Urasil dan toluene terhadap konsentrasi asetonitril sebagai fasa gerak. Kolom, PETRA-EDMA kolom A (100 x 0,32 mm i.d); Analit 0,1\% (w/v) masing-masing urasil dan toluen; fasa gerak, Acetonitril 60-100\%; Volume injeksi, 0,02 $\mu \mathrm{L}$; Detektor, UV detector 256 $\mathrm{nm}$; Kecepatan alir fasa gerak, $2 \mu \mathrm{L} / \mathrm{menit}$.

\section{Kesimpulan}

Sebuah metode sederhana dan cepat dalam pembuatan suatu kolom pemisah berbasis MixedMode Liquid Chromatography (MMLC) telah berhasil dilakukan, pembuatan kolom monolit PETRA-EDMA berdasarkan reaksi polimerisasi langsung di dalam kapiler fused silica tube. Kolom monolit A dengan rasio 35/65 (monomer/porogen) merupakan kondisi optimum dan dapat digunakan dalam memisahkan campuran senyawa fenol, pirogalol dan pirokatekol berdasarkan mekanisme interasi Reverse Phase (RP) pada kromatografi cair sistem kapiler. Kemampuan propertis HILIC dari monolit PETRA-EDMA dalam memisahkan urasil dan toluen juga telah berhasil diuji. Urasil yang bersifat polar dan toluen yang bersifat non polar dapat dipisahkan dengan interaksi HILIC serta memiliki transisi interaksi HILIC pada konsentrasi asetonitril 90\%.

\section{Ucapan Terimakasih}

Kami ingin mengucapkan terimakasih kepada Prof. Toyohide Takeuchi dan Prof. Lee Wah Lim, Chemistry and Biomolecular Science, Faculty of Engineering, Gifu University dan Prof. Fuseng Li, River Basin Research Center, Gifu University, Jepang yang telah memfasilitasi terlaksananya penelitian ini.

\section{Daftar Pustaka}

[1] M. C. Icardo, S. T. Cartas, S. M. Lloret, C. G. Benito, E. C. Correa, E. F. S. Alfonso, G. R. Ramos, J. M. H. Martínez, Preparation of organic monolithic columns in polytetrafluoroethylene tubes for reversed-phase liquid chromatography, Analytica Chimica Acta, vol. 960, 2017, pp 160-167.

[2] B. F. Mann, A. A. Makarov, H. Wang, C. J. Welch, Effects of pressure and frictional heating on protein separation using monolithic columns in reversed-phase chromatography, Journal of Chromatography A, Vol. 1489, 2017, pp. 58-64.

[3] K. Liu, P. Aggarwal, H. D. Tolley, J. S. Lawson, M. L. Lee., Fabrication of highly cross-linked reversed-phase monolithic columns via living radical polymerization. Journal of Chromatography A, Vol. 1367, 2014, pp 90-98.

[4] I. Iswaldi, A. M. G. Caravaca, J. L. Sánchez, D. A. Román, A. S. Carretero, A. F. Gutiérrez, Profiling of phenolic and other polar compounds in zucchini (Cucurbita pepo L.) by reverse-phase highperformance liquid chromatography coupled to quadrupole time-of-flight mass spectrometry. Food Research International, Vol. 50, 2013, pp. 77-84. 
[5] M. L. Chen, L. Li, B. F. Yuan, Q. Ma, Y. Q. Feng, Preparation and characterization of methacrylatebased monolith for capillary hydrophilic interaction chromatography, Journal of Chromatography A, vol. 1230, 2012, pp. 54-60.

[6] T. Ikegami, H. Fujita, K. Horie, K. Hosoya, N. Tanaka, HILIC mode separation of polar compounds by monolithic silica capillary columns coated with polyacrylamide, Analytical and Bioanalytical Chemistry, Vol. 386, 2006, pp. 578-585.

[7] Y. Li, H. D. Tolley, M. L. Lee, Poly[hydroxyethyl acrylate-co-poly(ethylene glycol) diacrylate] Monolithic Column for Efficient Hydrophobic Interaction Chromatography of Proteins, Anal. Chem., Vol. 81, 2009, pp. 9416-9424.

[8] P. Jandera, M. Stan`ková, The Effects of the Column Length on the Effciency of Capillary Zwitterionic Organic Polymer Monolithic Columns in HILIC Chromatography, Chromatographia, Vol. 78, 2015, pp. 853-859.

[9] S. L. Lin, M. R. Fuh, Preparation and characterization of vinylimidazole-based polymer monolithic stationary phases for reversed-phase and hydrophilic interaction capillary liquid chromatography, Talanta. Vol.187, 2018, pp. 73-82.

[10] P. Jandera, J. Urban, V. Skeríková, P. Langmaier, R. Kubícková, J. Planeta, Polymethacrylate monolithic and hybrid particle-monolithic columns for reversed-phase and hydrophilic interaction capillary liquid chromatography, Journal of Chromatography A, Vol. 1217, 2010, pp. 22-33.

[11] C. N. Cain, A. V. Forzano, S. C. Rutan, M. M. Collinson, Destructive stationary phase gradients for reversed-phase/hydrophilic interaction liquid chromatography, Journal of Chromatography A, Vol. 1570, 2018, pp. 82-90.

[12] S. L. Lin, M. M. Fuh, Preparation and characterization of vinylimidazole-based polymer monolithic stationary phases for reversed-phase and hydrophilic interaction capillary liquid chromatography, Talanta, Vol. 187, 2018, pp. 73-82.

[13] H. Zou, X. Huang, M. Ye, Q. Luo, Monolithic stationary phases for liquid chromatography and capillary electrochromatography, Journal of Chromatography A, vol. 954, 2002, pp. 5-32.

[14] A. Rahayu, L. W. Lim, T. Takeuchi. Polymer monolithic methacrylate base modified with tosylatedpolyethylene glycol monomethyl ether as a stationary phase for capillary liquid chromatography. Talanta, Vol. 134, 2015, pp. 232-238.

[15] R. Linda, L. W. Lim, T. Takeuchi. Methacrylate-based Diol Monolithic Stationary Phase for the Separation of Polar and Non Polar Compounds in Capillary Liquid Chromatograph. Anal. Sci., Vol. 29, 2013, pp. 631-635. 